Research Article

\title{
SPI-Based Spatiotemporal Drought over Sri Lanka
}

\author{
N. S. Abeysingha $(i)$ and U. R. L. N. Rajapaksha \\ Department of Agriculture Engineering and Soil Science, Faculty of Agriculture, Rajarata University of Sri Lanka, \\ Anuradhapura, Sri Lanka
}

Correspondence should be addressed to N. S. Abeysingha; nabeysingha@gmail.com

Received 23 October 2019; Revised 7 December 2019; Accepted 12 December 2019; Published 21 January 2020

Academic Editor: Gabriele Buttafuoco

Copyright (c) 2020 N. S. Abeysingha and U. R. L. N. Rajapaksha. This is an open access article distributed under the Creative Commons Attribution License, which permits unrestricted use, distribution, and reproduction in any medium, provided the original work is properly cited.

\begin{abstract}
Drought is one of the most significant hazards in Sri Lanka. Status of drought in Sri Lanka was assessed using Standardized Precipitation Index (SPI) at 3, 6, and 12 months' time scales using monthly rainfall (1970 to 2017) data of 54 weather stations. The frequency of drought events was evaluated using SPI, and trend of SPI was also detected using the Mann-Kendall (MK) test and Sen's slope estimator. The result based on SPI identified hydrological years 1975-76, 1982-83, 1986-87, 1988-89, 2000-01, 2001-02, 2013-14, and 2016-17 as drought years for 52, 32, 35, 33, 33, 31, 31, and 31\% of tested stations (54), respectively, at annual time scale. Comparison of the SPI at different time scales revealed that more drought events (SPI $\leq-1)$ occurred during Yala season than Maha cropping season. Considering the Thiessen polygon average rainfall, more frequent drought events occurred in the dry zone (57\%) than the wet (49\%) and intermediate zone (47\%) at the annual time scale. SPI trend results showed greater increase in drought (59\% of stations) during Yala seasons as compared to the Maha cropping season (15\% of stations) in Sri Lanka.
\end{abstract}

\section{Introduction}

Drought is one of the natural disasters which can cause huge damage to agriculture and other economic and social activities of the human system, and considerable damage is also caused to the ecosystem. It fundamentally occurs as a result of weather extremes that are driven by natural variability and climate change and also stimulated by anthropogenic influences [1]. Drought occurs naturally in nearly all climatic zones as a result of the reduction of precipitation from normal amounts for an extended period of time [2].

Drought is categorized into four types, namely, meteorological, agricultural, hydrological, and socioeconomic droughts [3]. Meteorological droughts are mainly determined on the basis of the degree of dryness in comparison to some normal quantity and the duration of the dry period.

Drought indices are a helpful tool for monitoring and evaluating the different kinds of drought since they facilitate communication of climate anomalies to numerous user audiences. Many indices have been developed to identify and quantify drought events based on different types of variables [4]. The Standardized Precipitation Index (SPI) is one of the most applied indices to analyze meteorological drought [5] as most other indices demand a number of other parameters other than rainfall. SPI was developed by McKee et al. [6] primarily for defining and monitoring droughts at different time scales. The main advantage of the application of this index is its versatility. SPI uses only rainfall data to deliver five major dimensions of a drought, i.e., duration, intensity, severity, magnitude, and frequency. Also, based on SPI, drought can be calculated at different time scales [3], and it can also be considered as an agricultural drought indicator [7]. A number of published studies are available in the literature on the use of SPI in assessing drought intensity in many countries $[4,8,9]$. However, application of SPI to assess the drought during recent past over entire Sri Lanka has not been reported in the literature to the best of authors' knowledge.

Sri Lanka is an island at the southern tip of India with a land area of nearly $65,610 \mathrm{~km}^{2}$ and population of 21.4 million 
[10] and is divided into three climatic zones, i.e., dry, wet, and intermediate, based on the total annual rainfall [11]. According to the Global Climate Risk Index 2019, Sri Lanka became the most affected countries along with Puerto Rico and Dominica [12]. Thus, Sri Lanka is extremely vulnerable to climate change impacts. In terms of people affected and relief provided, drought has been the most significant hazard in Sri Lanka, and Sri Lanka also serves as a case study in tropical regions for analysis of drought hazard and risk assessment [13]. Drought has affected many parts of the country intermittently as one of the serious natural hazards in Sri Lanka [14]. It is reported that 2001 drought severely affected dry and intermediate zone of the country while Hambantota area experienced prolonged severe drought during 2001 to 2002 [15]. Prolonged drought occurred in 2001-02 led to 1\% drop in the GDP growth rate in the country by particularly affecting hydropower generation and agriculture sector [13].

Drought studies in Sri Lanka so far have particularly focused on analysis of the spatial variations $[16,17]$, severity and duration of drought mostly in part of the country [18], and spatial extent and temporal evolution of drought [19]. Most of these studies are in relation to dry zone areas of Sri Lanka. However, Lyon et al. [13] studied the relationship between SPI and drought relief payments in the country and found the strongest relationships with a 9-month cumulative drought index. Herath et al. [20] analyzed monthly rainfall data using SPI to identify possible drought conditions only for the year 2015.

Moreover, it is rather rare to find drought trend analysis over entire Sri Lanka. It is worth to investigate the trend of drought over the entire country specially for drought mitigation and agricultural planning. It is also projected that most of the districts in the dry zone in Sri Lanka will face severe seasonal or year-round water scarcity by 2025 with present level of irrigation efficiency [21]. Hence, this paper analyzes the severity, frequency, and trend of meteorological drought over Sri Lanka during the recent past (1970 to 2017) using 48 years of rainfall data at 54 stations.

\section{Material and Methods}

2.1. Description of Data. Monthly precipitation data of 48 years (1970-2017) were collected from 54 meteorological stations (Table 1) from the Meteorological Department of Sri Lanka. The Meteorological Department of Sri Lanka is the nodal agency in Sri Lanka to record, quality check, and archive all meteorological data. The monthly rainfall values used in the study were prepared by the Meteorological Department of Sri Lanka, and data quality is maintained by them $[22,23]$.

Although there are only 54 stations used in this study, the stations are well distributed across the three climatic zones, i.e., dry, intermediate, and wet zones, of Sri Lanka (Figure 1) and hence adequately showed the climatic spatial variability in the country. There were missing values in few stations, and Table 1shows the missing values as a percentage, and missing values were filled using the regression and normal ratio method.
2.2. Meteorological Drought Analysis. Standardized Precipitation Index (SPI) was used to evaluate the drought both the short-term (3 and 6 months) and the long-term (12 months) time scales. In order to calculate the SPI index, for each time scale, the variability of precipitation totals is described by a gamma distribution and then transformed to a normal distribution [6]. The gamma distribution is defined by its frequency or probability density function:

$$
g(x)=\frac{1}{\beta^{a} \Gamma(a)} x^{a-1} e^{-(x / \beta)}, \quad \text { for } x>0,
$$

where $a$ and $\beta$ are the shape and scale parameters, respectively, $x$ is the precipitation amount, and $\Gamma(a)$ is the gamma function. Maximum likelihood estimations of $a$ and $\beta$ are

$$
\begin{aligned}
& a=\frac{1}{4 A}\left[1+\sqrt{1+\frac{4 A}{3}}\right], \\
& \beta=\frac{\bar{x}}{a}, \quad \text { where } A=(\bar{x})-\frac{\sum \ln (x)}{n},
\end{aligned}
$$

where $n=$ number of observations.

The subsequent parameters are then used to find the cumulative probability of a recorded precipitation amount for the given month and time scale for the given location. Since the gamma function is undefined for $x=0$ and a precipitation distribution may contain zeros, the cumulative probability is computed as

$$
H(x)=q+(1-q) G(x)
$$

where $q$ is the probability of zero precipitation and $G(x)$ is the cumulative probability of the incomplete gamma function. The cumulative probability $H(x)$ is then transformed to the standard normal random variable $z$ with mean and variance of zero and one, respectively, which is the value of the SPI [24].

Analysis was done in different time sequence, and time duration October to September was used as the hydrological year $\left(\mathrm{SPI}_{12}\right)$, and October to March and April to September were used as 6-month time scale $\left(\mathrm{SPI}_{6}\right)$ as these periods are cropping seasons of Maha and Yala, respectively, in Sri Lanka. October to December, January to March, April to June, and July to September were used as 3-month time scale $\left(\mathrm{SPI}_{3}\right)$. Calculated SPI values were compared with the SPI classification values for dryness/wetness category to indicate the status of the drought (Table 2).

2.3. Drought Frequency Analysis. Drought frequencies were calculated for dry, wet, and intermediate zones separately. For this purpose, average rainfall for three climate zones was calculated separately using the Thiessen polygon method first. Then, these average rainfall was used in computing SPI for three climatic zones separately and the resulted SPI was used in frequency calculation. For this frequency calculation, the drought was defined as SPI $<0$ [25]. Also, the frequency of occurrence of drought events more or less than $50 \%$ was calculated based on the calculated SPI in each station. 
TABLE 1: Geographical coordinates of meteorological stations used for the analysis.

\begin{tabular}{|c|c|c|c|c|}
\hline No & Name of the station & Latitude & Longitude & Missing value (\%) \\
\hline \multicolumn{5}{|c|}{ Dry zone } \\
\hline 1 & Allai & 8.4 & 81.32 & 4.8 \\
\hline 2 & Ampara & 7.28 & 81.67 & 1.2 \\
\hline 3 & Angamedilla & 7.85 & 80.92 & 2.1 \\
\hline 4 & Anuradhapura & 8.35 & 80.38 & 0 \\
\hline 5 & Bakamuna & 7.77 & 80.82 & 1.2 \\
\hline 6 & Batticaloa & 7.72 & 81.7 & 0 \\
\hline 7 & Diyabeduma & 7.93 & 80.87 & 1.1 \\
\hline 8 & Hambanthota & 6.12 & 81.13 & 0.2 \\
\hline 9 & Hingurakgoda & 8.05 & 80.95 & 4.4 \\
\hline 10 & Iranamadu & 9.35 & 80.4 & 4.1 \\
\hline 11 & Jaffna & 9.68 & 80.03 & 1.4 \\
\hline 12 & Kalawewa & 8 & 80.53 & 2.7 \\
\hline 13 & Kannukkeni & 9.2 & 80.8 & 6.6 \\
\hline 14 & Kanthale & 8.35 & 80.98 & 1.6 \\
\hline 15 & Mahailuppallama & 8.12 & 80.47 & 1.6 \\
\hline 16 & Mannar & 8.98 & 79.92 & 0 \\
\hline 17 & Maradankadawala & 8.13 & 80.57 & 3.9 \\
\hline 18 & Medawachchiya & 8.55 & 80.48 & 2.1 \\
\hline 19 & Minneriya & 8.05 & 80.9 & 3.5 \\
\hline 20 & Murunkan & 8.83 & 80.05 & 0.9 \\
\hline 21 & Pavatkulam & 8.68 & 80.43 & 3.2 \\
\hline 22 & Pothuvil & 6.88 & 81.83 & 0.9 \\
\hline 23 & Puttalam & 8.03 & 79.83 & 0.2 \\
\hline 24 & Tissamaharama & 6.28 & 81.3 & 1.6 \\
\hline 25 & Trincomalee & 8.58 & 81.25 & 1.4 \\
\hline \multicolumn{5}{|c|}{ Intermediate zone } \\
\hline 26 & Badulla & 6.98 & 81.05 & 0 \\
\hline 27 & Bandarawela & 6.83 & 80.98 & 0 \\
\hline 28 & Chilaw & 7.58 & 79.78 & 1.6 \\
\hline 29 & Dandeniya & 6 & 80.65 & 1.4 \\
\hline 30 & Kurunegala & 7.47 & 80.37 & 0 \\
\hline 31 & Nikaweratiya & 7.75 & 80.12 & 9.6 \\
\hline 32 & Wellawaya & 6.73 & 81.1 & 2.1 \\
\hline \multicolumn{5}{|c|}{ Wet zone } \\
\hline 33 & Alupolla & 6.72 & 80.58 & 0.4 \\
\hline 34 & Ambepussa & 7.28 & 80.17 & 1.2 \\
\hline 35 & Avissawella & 6.92 & 80.18 & 3.7 \\
\hline 36 & Chesterford & 7.07 & 80.18 & 4.3 \\
\hline 37 & Colombo & 6.9 & 79.87 & 0 \\
\hline 38 & Deniyaya & 6.35 & 80.62 & 1.8 \\
\hline 39 & Galle & 6.03 & 80.22 & 0 \\
\hline 40 & Galthura & 6.7 & 80.28 & 1.6 \\
\hline 41 & Geekiyanakanda & 6.6 & 80.12 & 1.6 \\
\hline 42 & Halwathura & 6.72 & 80.2 & 1.1 \\
\hline 43 & Hanwella & 6.88 & 80.12 & 0.4 \\
\hline 44 & Henarathgoda & 7.1 & 79.98 & 1.4 \\
\hline 45 & Kaluthara & 6.58 & 79.95 & 3.4 \\
\hline 46 & Katugastota & 7.33 & 80.63 & 0 \\
\hline 47 & Katunayaka & 7.17 & 79.88 & 0 \\
\hline 48 & Maliboda & 6.88 & 80.43 & 7.1 \\
\hline 49 & Matale & 7.47 & 80.62 & 0.2 \\
\hline 50 & Mawarella & 6.2 & 80.58 & 4.4 \\
\hline 51 & Nuwara Eliya & 6.97 & 80.77 & 0 \\
\hline 52 & Pasyala & 7.15 & 80.13 & 1.1 \\
\hline 53 & Peradeniya & 7.27 & 80.6 & 7.9 \\
\hline 54 & Ratnapura & 6.68 & 80.4 & 0 \\
\hline
\end{tabular}

2.4. Statistical Methods for Trend Analysis. In order to detect the drought trend using SPI as drought indicator over Sri Lanka, we used the most commonly used nonparametric
Mann-Kendall (MK) test $[26,27]$ together with Sen's slope estimator. The Mann-Kendall test statistic $S$ can be expressed as 


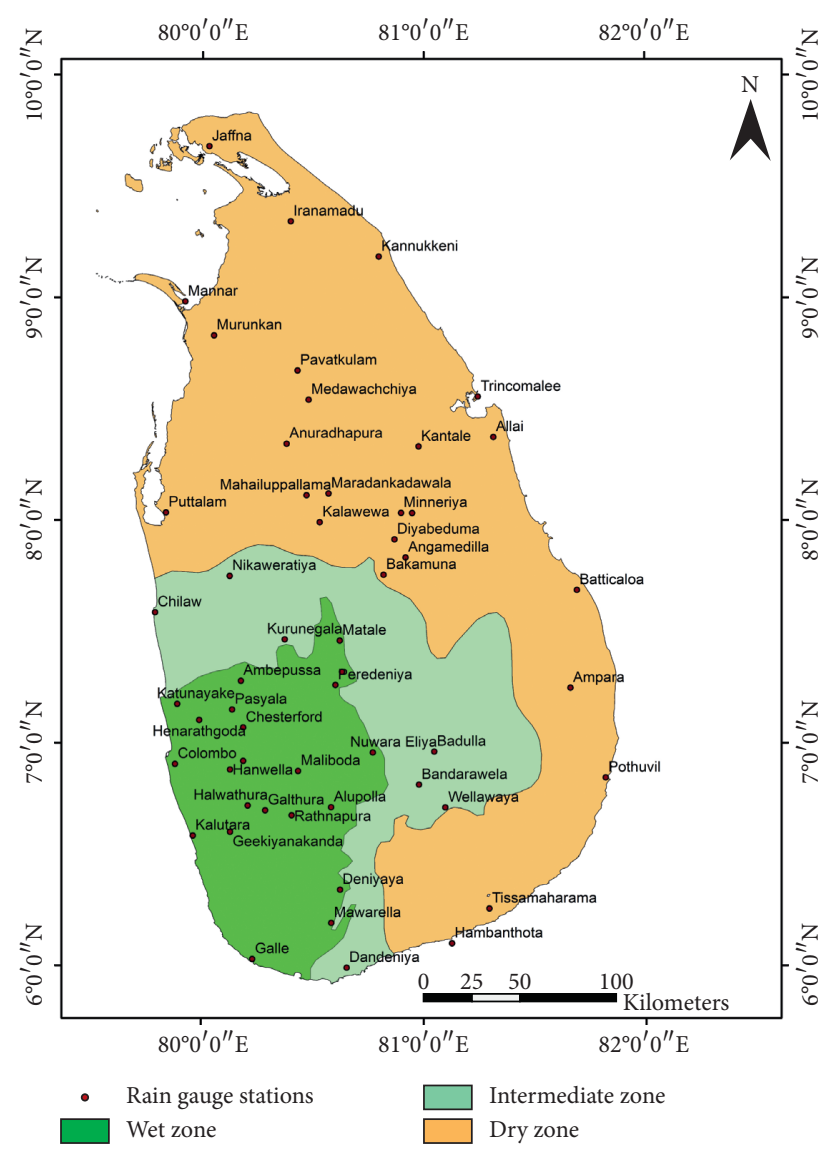

FIGURE 1: Geographical distribution of meteorological stations used in the study.

TABLE 2: Dryness/wetness category according to SPI value [6].

\begin{tabular}{lc}
\hline SPI value & Class \\
\hline SPI $\geq 2.00$ & Extremely wet \\
$1.50 \leq$ SPI $<2.00$ & Severely wet \\
$1.00 \leq$ SPI $<1.50$ & Moderately wet \\
$0.00 \leq$ SPI $<1.00$ & Mildly wet \\
$-1.00 \leq$ SPI $<0.00$ & Mild drought \\
$-1.50 \leq$ SPI $<-1.00$ & Moderate drought \\
$-2.00 \leq \mathrm{SPI}<-1.50$ & Severe drought \\
SPI $<-2.00$ & Extreme drought \\
\hline
\end{tabular}

$$
\begin{aligned}
& S=\sum_{i=1}^{n-1} \sum_{j=i+1}^{n} \operatorname{sign}\left(X_{j}-X_{i}\right), \\
& \operatorname{sign}\left(X_{j}+X_{i}\right)\left\{\begin{array}{l}
+1\left(X_{j}<X_{i}\right) \\
0\left(X_{j}=X_{i}\right), \\
-1\left(X_{j}<X_{i}\right)
\end{array}\right.
\end{aligned}
$$

where $n$ is the number of data and $x$ is the data point at times $i$ and $j(j>i)$. The variance of $S$ is as follows:

$$
\operatorname{var}(S)=\frac{\left[n(n-1)(2 n+5)-\sum_{i}^{m} t_{i} i(i-1)(2 i+5)\right]}{18},
$$

where $t_{i}$ is the number of ties of extent $i$ and $m$ is the number of tied groups for $n$ larger than 10 .

The Mann-Kendall test would moreover confirm the existence of a positive or negative trend for a confidence level of 0.05 .

Finally, Şen's method [28] was applied to estimate the true slope of a linear trend. To derive an estimate of the slope, $Q$, the slopes all data pairs are calculated as follows:

$$
Q_{i}=\frac{\left(x_{j}-x_{k}\right)}{j-k}, \quad i=1,2, \ldots, N, j>k,
$$

where $x_{j}$ and $x_{k}$ are data values at time $j$ and $k$. The median of the $N$ values of $Q_{i}$ is Sen's estimator of the slope [29].

However, for autocorrelated data, the modified Mann-Kendall test by Hamed and Ramachandra Rao [30] was used in this study by checking the lag one autocorrelation. This method is robust in presence of autocorrelation and is based on modified variance of the MK test.

As the MK test indicates only the trend direction, magnitude of the trend was detected using Sen's slope estimator. If a linear trend is present in a time series, then the true slope (change per unit time) can be estimated by using a simple nonparametric procedure developed by Sen [28]. Sen's slope for a monotonic increasing or decreasing time $(t)$ series $f(t)$ is computed as

$$
f(t)=Q t+B
$$

where $Q$ is the slope of the trend $f(t)$ and $B$ is the intercept. To determine $Q$ in equation (7), slopes between each data pair are calculated using the following equation:

$$
Q_{i}=\left[\frac{\left(X_{j}-X_{k}\right)}{j-k}\right], \quad \text { where } j<k \text {. }
$$

If there are $n$ values of $x_{j}$ in the time series, then there will be $N=n(n-1) / 2$ slope estimates of $Q_{i}$. Sen's estimator of slope is the median of these $N$ values of $Q_{i}$.

\section{Results and Discussion}

3.1. Meteorological Drought Analysis at Different Rainfall Stations Using SPI. Being an island of $65,610 \mathrm{~km}^{2}$, the climate of Sri Lanka is represented well by spatially distributed 54 rainfall stations, and we assessed drought events in 54 meteorological stations using SPI at 3, 6, and 12 months' time scales using 1970-2017 rainfall data.

Annual rainfall of each of the 54 stations was subjected to SPI analysis, and we identified nine hydrological years 197576, 1982-83, 1986-87, 1988-89, 2000-01, 2001-02, 2003-04, 2013-14, and 2016-17 as drought years (SPI $<-1)$ for 52, 32, $35,33,33,31,30,31$, and $31 \%$ of tested stations, respectively (Figure 2). Among them, the 1975-76 hydrological year showed the maximum number of drought events in different stations (52\% of stations) than other years (Figure 2).

Previous studies showed 2014 [18] and 2001-02 [13] as drought years in Sri Lanka. Impact of disasters in Sri Lanka published in 2016 [31] reported severe drought events in 2001, 2004, 2012, and 2014. Thus, SPI analysis confirms these 


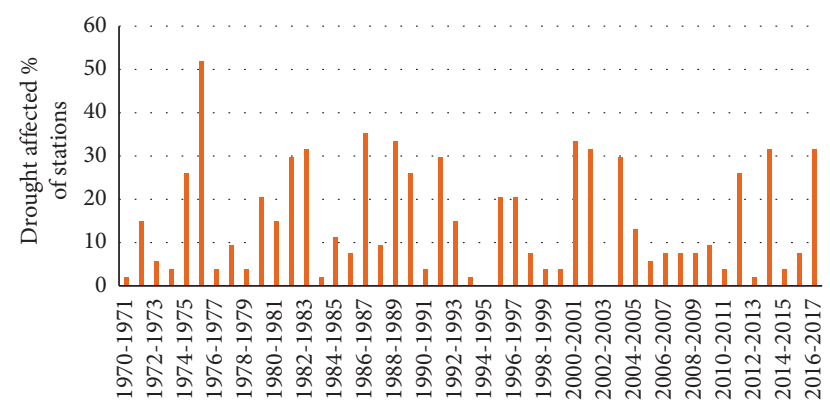

Figure 2: No. of stations (\%)showing drought events in each hydrological year (1970 to 2017).

historical drought situations over the country though SPI uses only rainfall as an input.

If the SPI values are below -2.00 , then those events are referred to be extreme drought events [6]. Accordingly, the year 1975-76 can be considered as extreme drought year for eight out of 54 stations (Figure not shown). These stations were Angamedilla (-2.23), Anuradhapura (-2.09), Hanwella (-2.32), Hingurakgoda (-2.44), Mannar (-2.26), Matale (-2.6), Murunkan (-2.03), and Puttalam (-2.26). Analysing these extreme drought events is of great importance for the design and management of water resources systems.

Figure 3 shows the occurrence of drought events (SPI $\leq-1)$ during Yala and Maha seasons in Sri Lanka during 1970 to 2017 as a percentage considering 54 rainfall stations. Comparatively, more number of stations showed the occurrence of drought events during Yala than Maha cropping seasons (Figure 3). Moreover, there is moderate $(-1.50 \leq \mathrm{SPI}<-1.00)$, severe $(-2.00 \leq \mathrm{SPI}<-1.50)$, or extreme drought event $(\mathrm{SPI}<-2.00)$ during Yala season of 1970-71, 1985-86, 1993-94, 1999-00, 2010-11, and 2012-13 hydrological years. Main rain source during this time is Southwest Monsoon (SWM), and frequent occurrence of drought events during these seasons indicates the uncertainty and variability of rainfall during SWM. This study confirms that Yala cropping season is more prone to drought than Maha season. In general, there is relatively low rainfall during the Yala season compared to the Maha cropping season [32] in Sri Lanka. Furthermore, it is shown that average seasonal rainfall in Kurunegala, Anuradhapura, and Polonnaruwa districts during the Yala was in decreasing trend over 1982 to 2012 period [33]. Rainfall trends of the Southwest Monsoon (SWM) which is the Yala season were also shown to be deceasing in trend over Sri Lanka during 1981 to 2010 [34]. These drying tendencies during Yala season may result in more number of drought events even in future during Yala season. However, 1973-74 and 1987-88 drought events have happened only during Maha season in most of the stations during which Northeast Monsoon prevails over the country. According to the analysis, 1988-89 Maha season became drought prone by $57 \%$ of stations while $57 \%$ and $50 \%$ of stations during 2011-12 and 1975-76, respectively, were drought prone during Yala seasons in Sri Lanka. It is observed that a few consecutive years showed the occurrence of drought events during the Yala season such as 2000 to 2002, 2004 to 2006, and 2010 to 2013. Consecutive

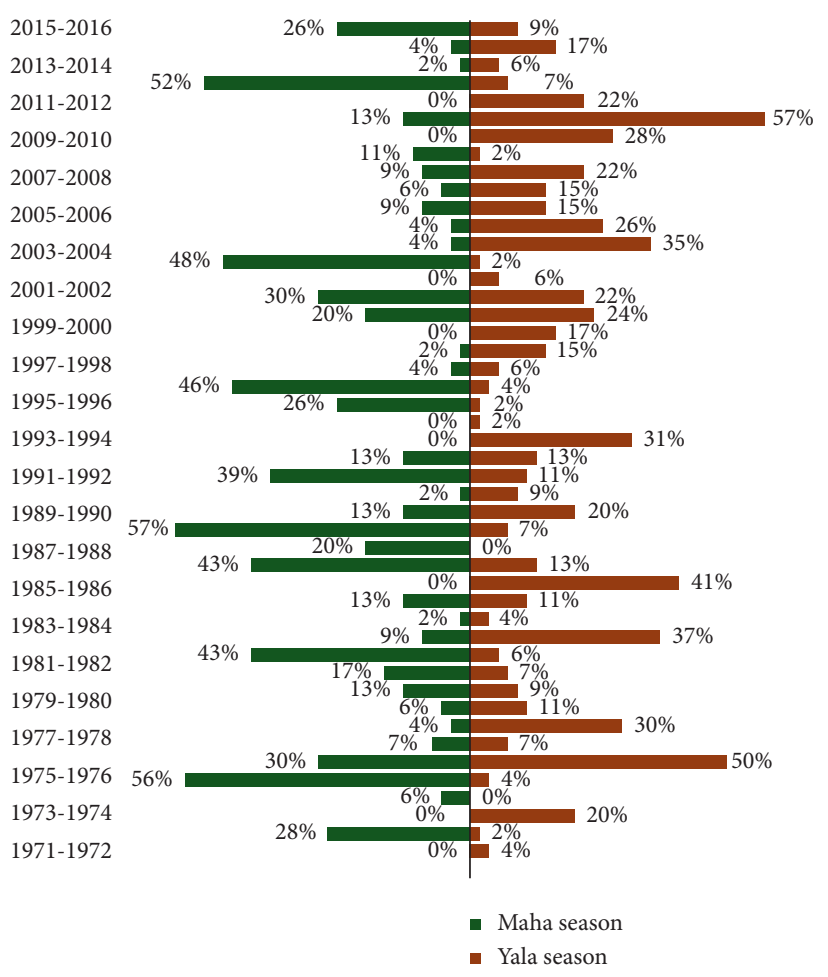

Figure 3: Occurrence of drought events (SPI $\leq-1)$ during Yala and Maha seasons as a \% of stations.

drought events definitely affect the potable water requirements and the economy of the farming community.

Analysis of SPI at 3-months (October-December) time scale $\left(\mathrm{SPI}_{3}\right)$ revealed drought in $78,43,37,57,31,43,43,57$, and $67 \%$ of tested stations during the hydrological years 1974-75, 1984-85, 1986-87, 1988-89, 1995-96, 2000-01, 2003-04, 2013-14, and 2016-17, respectively (Figure 4). Chesterford, Colombo, and Diyabeduma stations located in wet zone of the country showed more drought events than other stations during October-December $\left(\mathrm{SPI}_{3}\right)$ time scale. As Maha cropping season (September to March) starts during this time, the crop water requirements increase specially for paddy field preparation. Similarly, drought in $50,70,37,87,76$, and $57 \%$ of tested stations were found during the hydrological years 1971-72, 1979-80, 1981-82, 1982-83, 1991-92, and 1996-97, respectively, for SPI at January-March time scale (Figure 4). The number of drought events was higher for both Badulla and Kaluthara stations during this period. SPI at April-June time scale identified years 1975-76, 1982-83, and 1999-00, 2011-12, and 2016-17 as drought years for $43,39,39,52$, and $33 \%$ of tested stations, respectively. For April-June time scale, Hambantota station showed more drought events than other tested stations. April to August is generally the Yala cropping season to the country, and occurrence of drought situation during this season is likely to influence the food security of the country. Hydrological years 1975-76, 1977-78, 1989-90, 2001-02, and 2015-16 were found as drought years with 41, $39,39,54$, and $83 \%$ of tested stations showing drought, respectively, during July to September time scale (Figure 4). However, all the stations in the 2015-16 hydrological year 


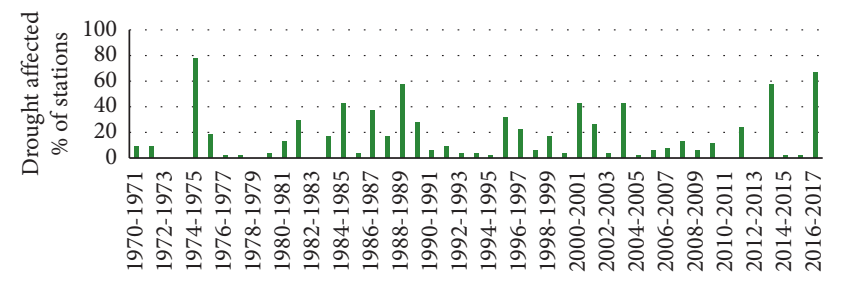

(a)

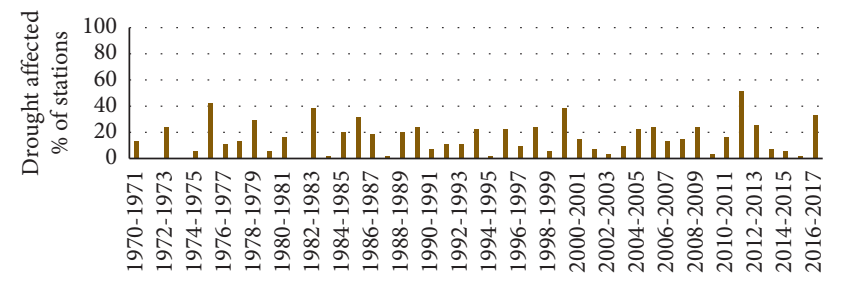

(c)

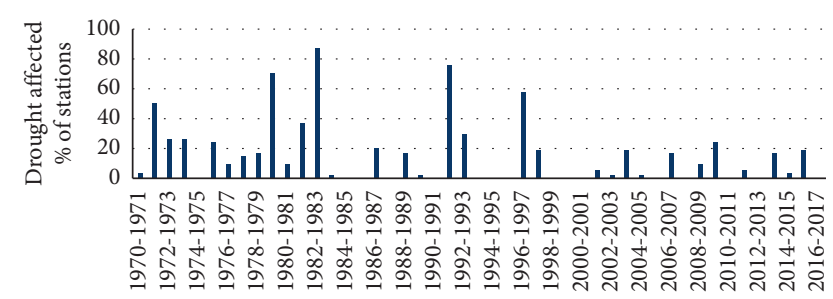

(b)

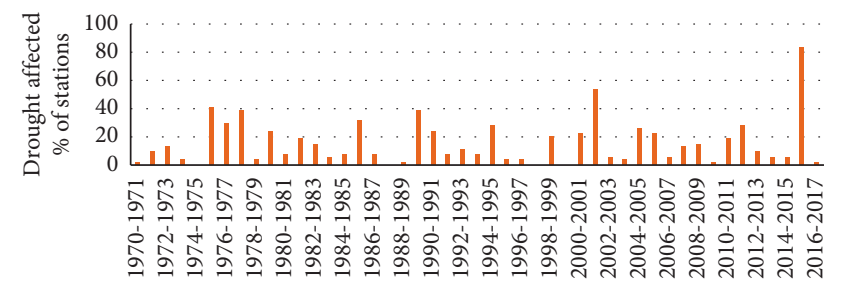

(d)

Figure 4: Percentage of stations showing drought events in $\mathrm{SPI}_{3}$. (a) October-December. (b) January-March. (c) April-June. (d) July-September.

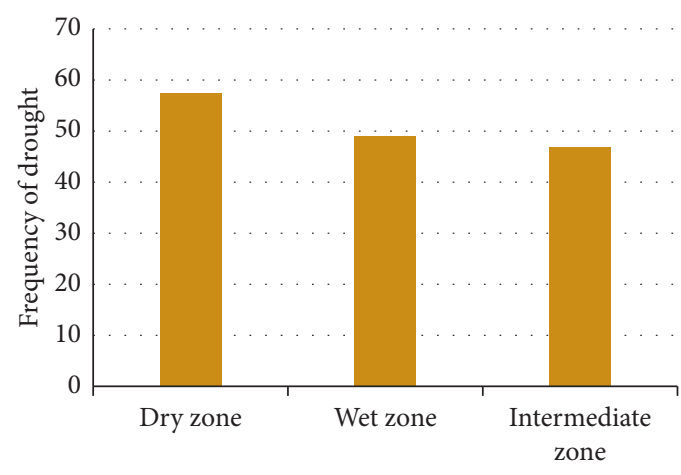

(a)

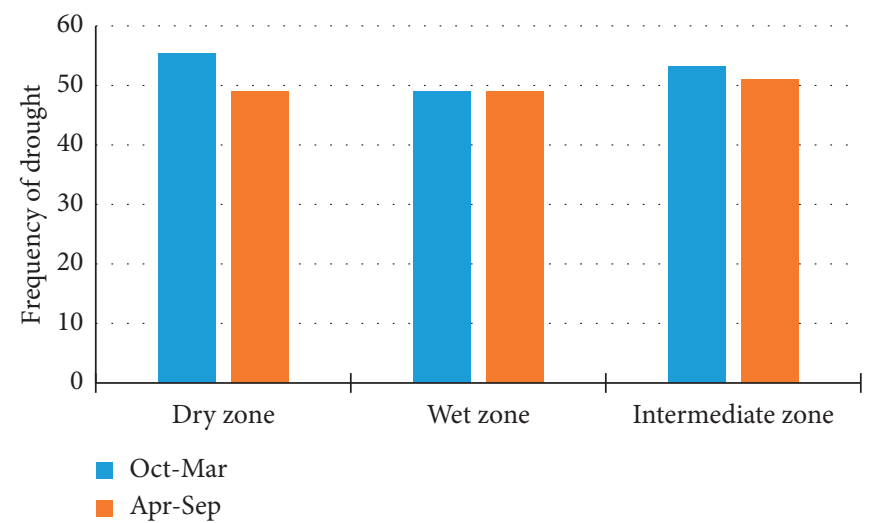

(b)

FIGURE 5: Frequency of drought in climatological zones at the (a) annual time scale and (b) 6-month time scale based on Thiessen polygon average rainfall for wet, dry, and intermediate zones.

showed the SPI values below zero, while 26 out of 54 stations showed the occurrence of extreme drought events during the end of the Yala season. Also, both Kalawewa and MahaIluppallama stations showed more drought events than other tested stations during the July-September time scale during the last 47 years.

\subsection{Frequency of Occurrence of Drought Events $(S P I<0)$ in the} Climatological Zones of Sri Lanka. Considering the calculated Thiessen polygon average rainfall for wet, dry, and intermediate zones, frequencies of occurrence of drought events in the climatological zones were separately calculated based on 6-month and annual SPI time scales. Accordingly, there were more frequent drought events that occurred in the dry zone (57\%) than the wet $(49 \%)$ and intermediate zone $(47 \%)$ at the annual time scale (Figure 5). At 6-month time scale, there were more frequent drought events that occurred in the dry zone (55\%) than the wet (49\%) and intermediate zone (53\%) during October-March (Maha season) time scale (Figure 5). During April-September (Yala season) time scale, both dry and wet zones showed a similar frequency of drought (48\%) but it was less than the intermediate zone (51\%) (Figure 5).

3.3. Trend Analysis of SPI for Rainfall Stations. We used the most commonly used Mann-Kendall test (MK) with Sen's slope estimator to detect the trend of meteorological drought in annual and 6-month SPI time scales during 1970 to 2017 over Sri Lanka. Figure 6 shows only the significant trend results of the Mann-Kendall test for annual and 6-month time scales (Maha and Yala).

Trend analysis of SPI at annual scale revealed decreasing trend of SPI only at two stations (Avissawella and Pavatkulam) exhibiting significant decreasing trend. However, 12 stations exhibited wetting tendency showing significant increasing trend for annual SPI. Thus, considering overall trend over the country, the country witnesses wetting 


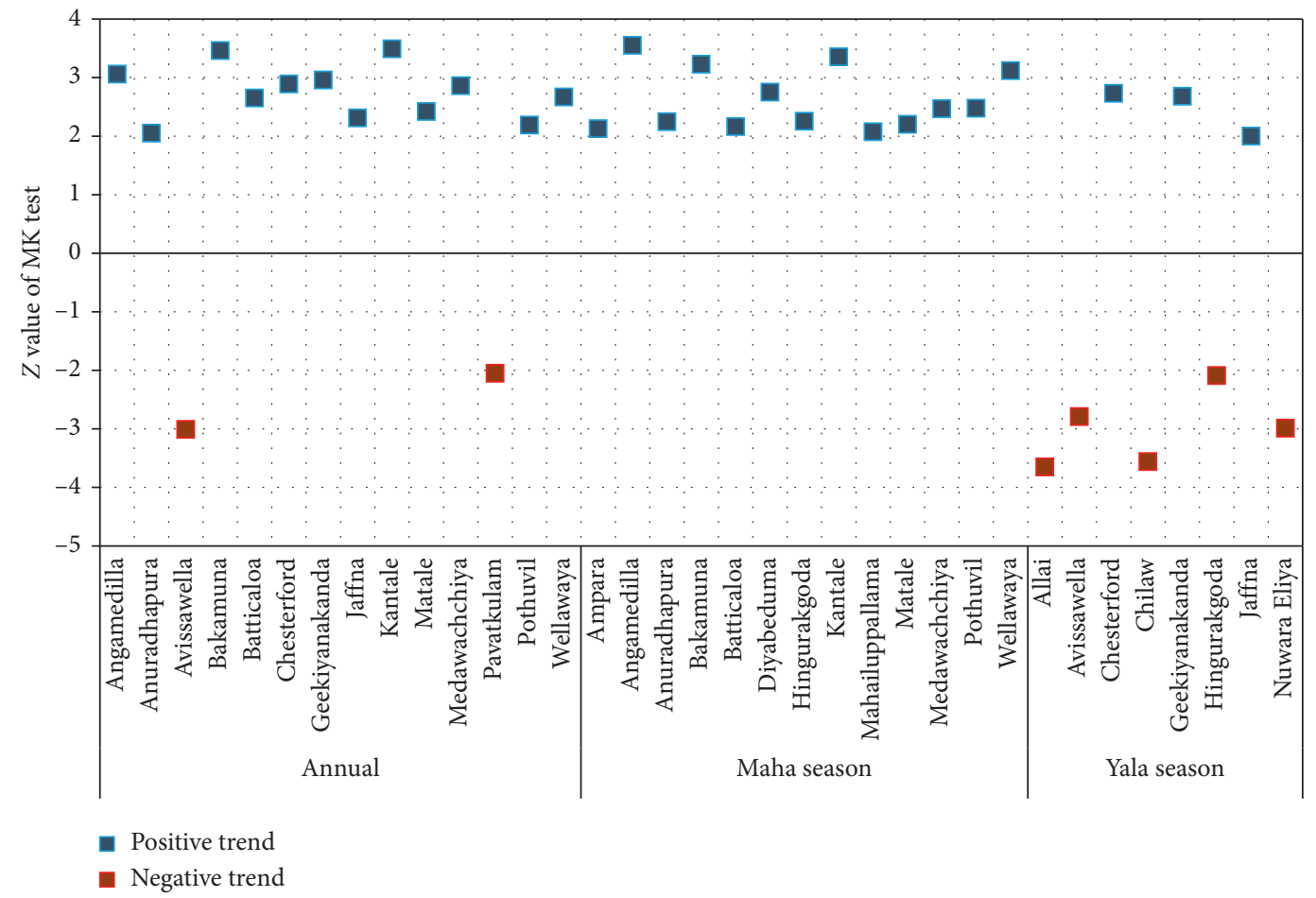

Figure 6: Summarized results of the MK test for SPI12 (Annual) and SPI6 (Maha and Yala seasons). Stations showing a significant trend at 0.05 level of significance are only shown.
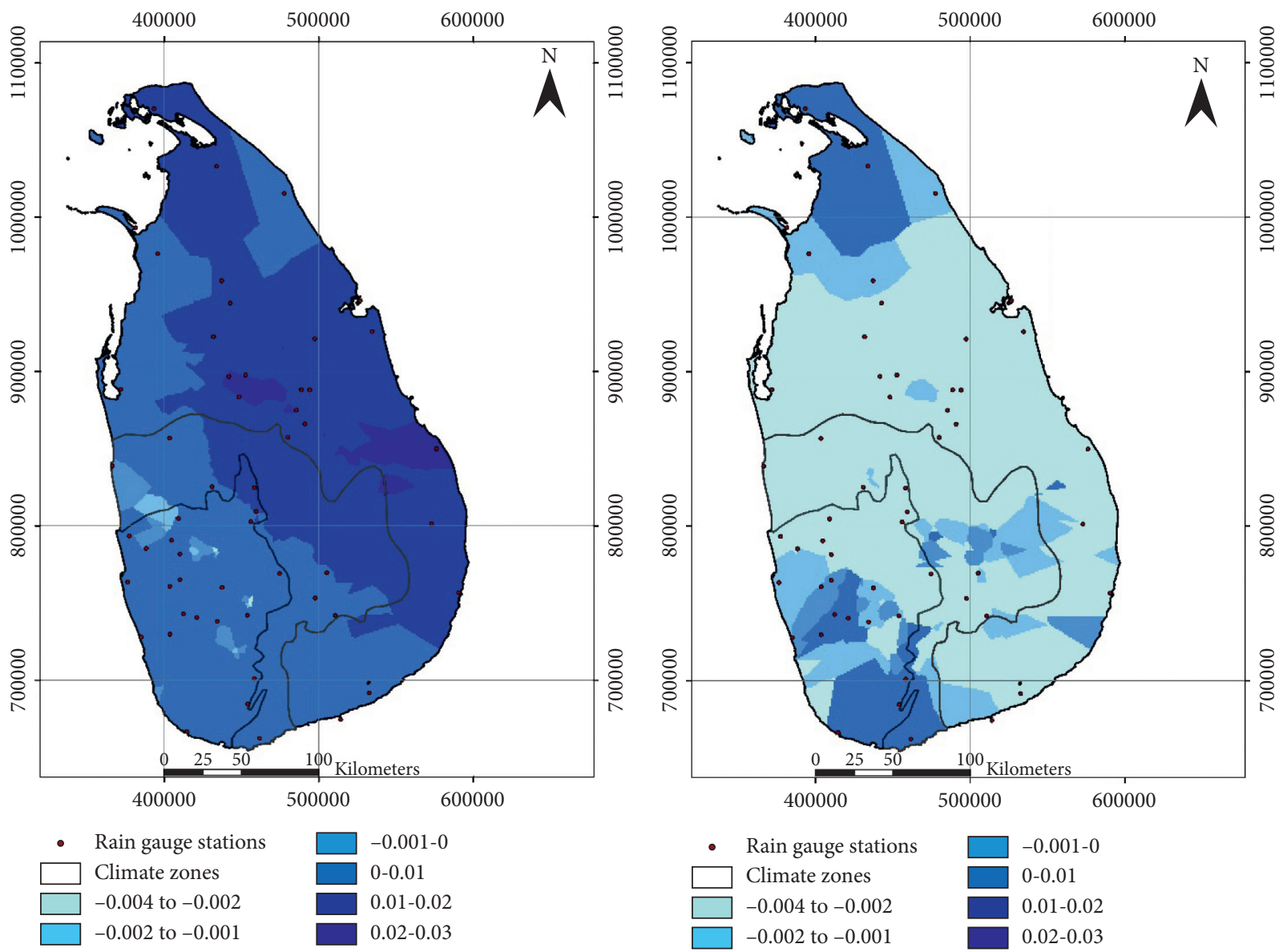

(b)

FIgURE 7: Continued. 


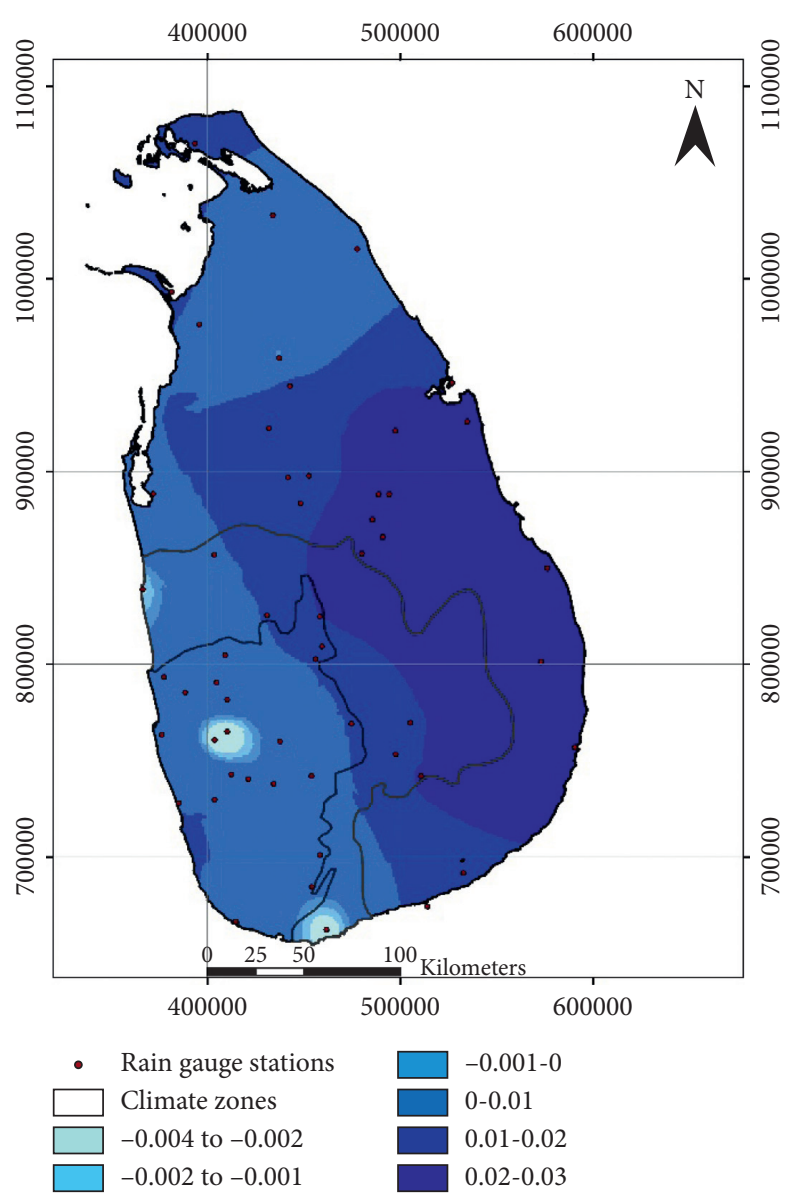

(c)

FIgURe 7: Drought trend over Sri Lanka in terms of the Sens' slope of SPI. (a) Annual; (b) Yala; and (c) Maha season.

tendency (decrease in drought events) in terms of $\mathrm{SPI}_{12}$ (Figure 6). Most of these stations showing wetting tendencies are located in dry zone of the country except Chesterford, Geekiyanakanda, and Matale. Nisansala et al. [35] analyzing the rainfall trend at 37 stations during the recent 31 years (1987-2017) showed an increasing annual rainfall trend over the country and further they showed a significant increase at four stations located in the dry zone, but only one station in the wet zone.

Considering $\mathrm{SPI}_{6}$ during Yala season, significant decreasing trends were observed in 5 stations, whereas none of the stations recorded decreasing trend during Maha cropping seasons. Only 3 stations showed significant wetting tendencies during Yala seasons, but 13 stations out of 54 stations displayed significant increasing trend (wetting) during Maha seasons in Sri Lanka during 1970 to 2017.These results indicate that rainfall during Yala seasons is in decreasing trend while it increases during Maha seasons. Wickramagamage [34] also showed a decreasing trend of SWM which brings rainfall during Yala season to the entire island and observed comparatively increasing trend during NEM (January to February) from a study conducted for the period 1981 to 2010.

To understand the spatial variation of drought trend at annual SPI time scale, Sen's slope values were interpolated for the entire country using Ordinary Kriging in ArcGIS
(10.2) (Figure 7). Figure 7 (a) shows that Eastern part of the country (part of dry and intermediate zone) getting wetter whereas some part of dry, intermediate, and wet zone getting dryer according to the annual SPI time scale. Similarly, eastern segment of the country is getting wetter during the Maha cropping season. However, during Yala season, most parts of the country are getting dryer except far north and southwestern part. A similar trend was observed for the rainfall trend analysis for Yala and Maha season during the 1987-2017 period using MK test [35].

Previous studies have revealed that droughts are related to cyclic global teleconnections such as El Nino Southern Oscillation (ENSO) and Indian Ocean Dipole (IOD) $[36,37]$. For example, De Silva and Hornberger [38] showed that there is high probability of occurrence of drought when both IOD and MEI (multivariate ENSO index) are positive and nonoccurrence of drought when both IOD and MEI are negative [38]. However, understanding the spatial variation of drought and their trends and frequency as recorded in the present study is also useful for the water resources planning in the country. Water resources and agricultural planners need to analyze cyclic teleconnections, drought trend, and frequency in developing water resources and allocation of water for different sectors and planning crops for different zones of the country for the food security. 


\section{Conclusions}

SPI was calculated at different time scales, but the analysis showed that more drought events $(\mathrm{SPI} \leq-1)$ occurred at April-September time scale (Yala season) than the 3month, 6-month (Maha season), and annual SPI time scales. During 1975-76 hydrological year, 52\% of stations showed drought more than other years while 8 out of 54 stations showed extreme drought events during annual SPI time scale. Drought analysis based on crop season, there were moderate, severe or extreme drought events occurred in 1970-71, 1985-86, 1993-94, 1999-00, 2010-11, and 201213 hydrological years during Yala season (April-September) only. During July-September SPI time scale, all the stations during the 2015-16 hydrological year showed the SPI values below zero while 26 out of 54 stations showed the occurrence of extreme drought events.

Based on Thiessen polygon average rainfall, there were more frequent drought events in the dry zone $(57 \%)$ than the wet $(49 \%)$ and intermediate zones (47\%) at the annual time scale. According to annual SPI time scale, stations in dry, intermediate, and wet zones showed more than $50 \%$ of the frequency of drought events at 72,71 , and $68 \%$ of stations, respectively. During Maha season, stations in dry and intermediate zones showed more than $50 \%$ of the frequency of drought events at $76 \%$ and $58 \%$ of stations, respectively, while the wet zone showed less than $50 \%$ of the frequency of drought at $59 \%$ of stations.

Based on the Mann-Kendall trend test, Allai, Avissawella, Chilaw, Hingurakgoda, and Nuwara Eliya stations showed a statistically significant decreasing trend during the Yala season. The spatial variation of drought trend showed that part of the dry, wet and intermediate zone located in Western and South-western getting dryer. Particularly, dry and part of the intermediate zone are getting dryer during the Yala cropping season. The results of this study suggest an immediate drought mitigation plan for drought-prone areas, especially for the Yala cropping season, for the reduction of the disaster of droughts.

\section{Data Availability}

The data are available at the Meteorological department of Sri Lanka data portal.

\section{Conflicts of Interest}

The authors declare that they have no conflicts of interest.

\section{References}

[1] J. Sheffield and E. F. Wood, "Global trends and variability in soil moisture and drought characteristics, 1950-2000, from observation-driven simulations of the Terrestrial Hydrologic Cycle," Journal of Climate, vol. 21, no. 3, pp. 432-458, 2008.

[2] A. Belayneh and J. Adamowski, "Standard precipitation index drought forecasting using neural networks, wavelet neural networks, and support vector regression," Applied Computational Intelligence and Soft Computing, vol. 2012, pp. 1-13, 2012.
[3] A. D. Malakiya and T. M. V. Suryanarayana, "Assessment of drought using standardized precipitation index (SPI) and reconnaissance drought index (RDI): a case study of amreli district," International Journal of Science and Research, vol. 5, no. 8, pp. 1995-2002, 2016.

[4] C. A. Karavitis, S. Alexandris, D. E. Tsesmelis, and G. Athanasopoulos, "Application of the standardized precipitation index (SPI) in Greece," Water, vol. 3, no. 3, pp. 787-805, 2011.

[5] B. Habibi, M. Meddi, P. J. J. F. Torfs, M. Remaoun, and H. A. J. Van Lanen, "Characterisation and prediction of meteorological drought using stochastic models in the semiarid Chéliff-Zahrez basin (Algeria)," Journal of Hydrology: Regional Studies, vol. 16, pp. 15-31, 2018.

[6] T. B. McKee, N. J. Doesken, and J. Kleist, "The relationship of drought frequency and duration to time scales," in Proceedings of the 8th conference on Applied Climatology, vol. 17, pp. 179-184, American Meteorological Society, Anaheim, CA, USA, January 1993.

[7] N. R. Patel, P. Chopra, and V. K. Dadhwal, "Analyzing spatial patterns of meteorological drought using standardized precipitation index," Meteorological Applications, vol. 14, no. 4, pp. 329-336, 2007.

[8] R. Meenakshi, M. Navamuniyammal, and S. Mahalingam, "Assessment of meteorological drought using Drinc and GIS in Tiruttani block of Thiruvallur district, Tamil Nadu, India," International Journal of Engineering Research and Technology, vol. 6, no. 5, pp. 1003-1011, 2017.

[9] T. Caloiero, P. Caloiero, and F. Frustaci, "Long-term precipitation trend analysis in Europe and in the Mediterranean basin," Water and Environment Journal, vol. 32, no. 3, pp. 433-445, 2018.

[10] Central Bank of Sri Lanka, "Central bank report," 2018, https://www.cbsl.gov.lk.

[11] M. Domroes, "Monsoon and land use in Sri Lanka," Geo Journal, vol. 3, no. 2, pp. 179-192, 1979.

[12] Germanwatch, “Global climate risk index 2019," 2019, https:// www.germanwatch.org/en/16046.

[13] B. Lyon, L. Zubair, V. Ralapanawe, and Z. Yahiya, "Finescale evaluation of drought in a tropical setting: case study in Sri Lanka," Journal of Applied Meteorology and Climatology, vol. 48, no. 1, pp. 77-88, 2009.

[14] R. K. W. G. Nianthi, "Mitigation and adaptation strategies: set up a drought task force (DTF) in Sri Lanka," in Proceedings of the National Conference on Understanding and Managing Unsettled Drought, pp. 26-32, Rajarata University of Sri Lanka, Anuradhapura, Sri Lanka, July 2017.

[15] S. Manesha, S. Vimukthini, and K. H. M. S. Premalal, "Develop drought monitoring in Sri Lanka using standardized precipitation index (SPI)," Sri Lanka Journal of Meteorology, vol. 1, pp. 64-71, 2015.

[16] N. Piratheeparajah and S. Raveendran, "Spatial variations of the flood and drought in the Northern Region of Sri Lanka," International Research Journal of Earth Sciences, vol. 2, no. 6, pp. 2321-2527, 2014.

[17] K. Navarathinam, M. A. Gusyev, A. Hasegawa, and J. Magome, “Agricultural flood and drought risk reduction by a proposed multi-purpose dam: a case study of the malwathoya river basin, Sri Lanka," in Proceedings of the 21st International Congress on Modelling and Simulation, Gold Coast, Australia, December 2015.

[18] E. Ekanayake and K. Perera, "Analysis of drought severity and duration using copulas in Anuradhapura, Sri Lanka," British 
Journal of Environment and Climate Change, vol. 4, no. 3, pp. 312-327, 2014.

[19] R. Lokuhetti, L. Zubair, J. Visvanathan, and A. Nijamdeen, "Drought monitoring for Sri Lanka: spatial extent and temporal evolution during the 2016-17 drought: 13-15," in Proceedings of the International Roundtable on the Impact of Extreme Natural Events:Science and Technology for Mitigation-2017, Colombo, Sri Lanka, December 2017.

[20] H. M. R. C. Herath, K. H. M. S. Premalal, A. Kaumadee, and Sanjeewani, "Analysis of standardized precipitation indices to identify for drought condition in 2015," Sri Lanka Journal of Meteorology, vol. 1, pp. 20-31, 2015.

[21] M. Samad, M. Aheeyar, J. Royo-Olid, and I. Arulingam, The Political and Institutional Context of the Water Sector in Sri Lanka: An Overview, p. 92, European Union, Luxembourg, Europe, 2017.

[22] B. A. Malmgren, R. Hulugalla, Y. Hayashi, and T. Mikami, "Precipitation trends in Sri Lanka since the 1870s and relationships to El Niño-southern oscillation," International Journal of Climatology, vol. 23, no. 10, pp. 1235-1252, 2003.

[23] H. Jayawardene, D. Sonnadara, and D. Jayewardene, "Trends of rainfall in Sri Lanka over the last century," Sri Lankan Journal of Physics, vol. 6, pp. 7-17, 2005.

[24] D. Tigkas, H. Vangelis, and G. Tsakiris, "DrinC: a software for drought analysis based on drought indices," Earth Science Informatics, vol. 8, no. 3, pp. 697-709, 2015.

[25] B. Liu, Z. Yan, J. Sha, and S. Li, "Drought evolution due to climate change and links to precipitation intensity in the haihe river basin," Water, vol. 9, no. 11, p. 878, 2017.

[26] H. B. Mann, "Nonparametric tests against trend," Econometrica, vol. 13, no. 3, pp. 245-259, 1945.

[27] M. G. Kendall, Rank Correlation Methods, Charles Griffin, London, UK, 1975.

[28] P. K. Sen, "Estimates of the regression coefficient based on kendall's tau," Journal of the American Statistical Association, vol. 63, no. 324, pp. 1379-1389, 1968.

[29] S. N. Rahmat, N. Jayasuriya, and M. A. Bhuiyan, "Trend analysis of drought using Standardized Precipitation Index in Victoria, Australia," in Proceedings of the 34th Hydrology and Water Resources Symposium, pp. 441-448, Sydney, Australia, November 2012.

[30] K. H. Hamed and A. Ramachandra Rao, "A modified MannKendall trend test for autocorrelated data," Journal of $\mathrm{Hy}$ drology, vol. 204, no. 1-4, pp. 182-196, 1998.

[31] Consortium of Humanitarian Agencies (CHA), Impact of Disasters in Sri Lanka, The Consortium of Humanitarian Agencies (CHA), Colombo, Sri Lanka, 2016.

[32] K. S. Sanjaya, T. Priyadarshana, and N. Wijayarathna, "Effect of rainfall abnormalities on rice yield in Hambanthota district, Sri Lanka," Asian Journal of Agriculture and Food Sciences, vol. 2, no. 6, pp. 494-499, 2014.

[33] H. G. A. S. Sathischandra, B. Marambe, and R. Punyawardena, "Seasonal changes in temperature and rainfall and its relationship with the incidence of weeds and insect pests in rice (Oryza sativaL) cultivation in Sri Lanka," Climate Change and Environmental Sustainability, vol. 2, no. 2, pp. 105-115, 2014.

[34] P. Wickramagamage, "Spatial and temporal variation of rainfall trends of Sri Lanka," Theoretical and Applied Climatology, vol. 125, no. 3-4, pp. 427-438, 2015.

[35] W. D. S. Nisansala, N. S. Abeysingha, A. Islam, and A. M. K. R. Bandara, "Recent rainfall trend over Sri Lanka (1987 to 2017)," International Journal of Climatology, 2019.

[36] C. F. Ropelewski and M. S. Halpert, "Quantifying southern oscillation-precipitation relationships," Journal of Climate, vol. 9, no. 5, pp. 1043-1059, 1996.
[37] J. Chandimala and L. Zubair, "Predictability of stream flow and rainfall based on ENSO for water resources management in Sri Lanka," Journal of Hydrology, vol. 335, no. 3-4, pp. 303-312, 2007.

[38] T. De Silva and G. M. Hornberger, "Identifying El NiñoSouthern Oscillation influences on rainfall with classification models: implications for water resource management of Sri Lanka," Hydrology and Earth System Science, vol. 23, pp. 1905-1929, 2019. 